\title{
Physiological Responses of Cowpea (Vigna unguiculata) Under Irrigation With Saline Water and Biostimulant Treatment
}

\author{
Leonardo Vieira de Sousa ${ }^{1}$, Rayanne Maria Paula Ribeiro ${ }^{2}$, Manoel Galdino dos Santos ${ }^{2}$, \\ Fernando Sarmento de Oliveira ${ }^{2}$, Hugo Ferreira ${ }^{2}$, Francisco Rafael Rodrigues Gerônimo ${ }^{2}$, \\ Antônio Genilson Rodrigues Araújo ${ }^{2}$, Toshik Iarley da Silva ${ }^{3} \&$ Aurélio Paes Barros Júnior ${ }^{2}$ \\ ${ }^{1}$ Department of Plant Science and Environmental Sciences, Federal University of Paraíba, Areia, Paraíba, Brazil \\ ${ }^{2}$ Department of Agronomic and Forest Sciences, Federal Rural Semi-Arid University, Mossoró, Rio Grande do \\ Norte, Brazil \\ ${ }^{3}$ Department of Plant Science, Federal University of Viçosa, Viçosa, Minas Gerais, Brazil \\ Correspondence: Toshik Iarley da Silva, Department of Plant Science, Postgraduate Program in Plant Science, \\ Federal University of Viçosa, Campus Universitário, CEP: 36570-900, Viçosa, Minas Gerais, Brazil. E-mail: \\ iarley.toshik@gmail.com
}

Received: August 12, 2018

doi:10.5539/jas.v10n12p24

\author{
Accepted: September 18, 2018 \\ Online Published: November 15, 2018 \\ URL: https://doi.org/10.5539/jas.v10n12p24
}

\begin{abstract}
Cowpea (Vigna unguiculata) is one of the world's main crops, and it is a fundamental source of protein for semiarid regions population. In these regions, the use of high salts concentration water in irrigation systems is one of the major factors that contributes to reduced cowpea yield. One way to alleviate the negative effects of salinity is through the biostimulants application, which is a product that has beneficial substances to the plants metabolism. The aim of this study was to evaluate the application of biostimulant in cowpea cultivars under irrigation with saline water. The study was carried out in the Agrarian Sciences Center, of the Department of Agronomic and Forest Sciences of the Federal Rural University of the Semi-Arid, in the city of Mossoró, RN. The experimental design was completely randomized, with four replications. The treatments were arranged in 5 $\times 2 \times 2$ factorial scheme, with five doses of biostimulant $\left(0,15,30,45\right.$ and $\left.60 \mathrm{~mL} \mathrm{~L}^{-1}\right)$, two electrical conductivities of the irrigation water $\left(0.5\right.$ and $\left.5.0 \mathrm{dS} \mathrm{m}^{-1}\right)$, and two cowpea cultivars (IPA-206 and BRS Guariba). The evaluated characteristics were: chlorophyll content index, stomatal conductance, net photosynthesis, internal $\mathrm{CO}_{2}$ concentration, transpiration rate, shoot height, stem diameter and shoot dry mass. The biostimulant application was not efficient in attenuating the salinity stress effect on the development of cowpea cultivars. The higher biostimulant concentrations along with the use of saline water increased the negative effects of salinity on the cowpea plants physiology. There was no difference between the cultivars regarding the tolerance to saline stress and the application of biostimulant.
\end{abstract}

Keywords: Ascophyllum nodosum, salinity stress, gas exchange

\section{Introduction}

The cowpea (Vigna unguiculata (L.) Walp.) is one of the main sources of vegetable protein in tropical and subtropical regions of the world (Santos et al., 2014). In this scenario, Brazil is classified as the world's third largest producer, with estimated production of 749.4 thousand tons for the 2017/2018 harvest (CONAB, 2018). In the Brazilian national ranking, the Northeast region is the largest producer, with approximately $51 \%$ of the national production, produced in an area of 1,134.3 hectares. Despite the high productive potential, the average yield of cowpea in the Northeast is still low, with only $336 \mathrm{~kg} \mathrm{ha}^{-1}$ (CONAB, 2018).

Several factors (low rainfall, salinity of soil and of the irrigation water, high temperature, among others) are responsible for the low cowpea productivity in the Northeast region, the use of water with high salinity levels stands out (Silva et al., 2013). Although cowpea is classified as a moderately salt tolerant crop, with a salinity threshold of $3.3 \mathrm{dS} \mathrm{m}^{-1}$ (Ayers \& Westcot, 1999). Researchers have observed that the use of saline water in irrigation directly impairs its development, affecting plant height, stem diameter and dry matter production, in addition to interfere in physiological characteristics, such as stomatal conductance, transpiration and net photosynthetic rate (Prazeres et al., 2015; Aquino et al., 2017). 
The development of irrigation management strategies, especially those aimed at mitigating the effects of saline stress on plants (Silva et al., 2013; Oliveira et al., 2015), is one way to increase the cowpea productivity in regions with salinity problems. Among these strategies, the application of natural or synthetic substances that alleviate the salinity stress on plants may be an important alternative (Oliveira et al., 2017). Several studies have been conducted aiming the development of techniques that might alleviate the negative effects of irrigation with saline water, the use of biostimulants is among the techniques studied (Oliveira et al., 2013, 2017). Biostimulants are products that can assist plants in overcoming abiotic stresses, mainly due to their roles as hormonal and nutritional stimulants (Oliveira et al., 2016).

Many commercial products based on the seaweed extract Ascophyllum nodosum have been used as a biostimulant, which is an alternative source of nutrients to plants that leaves no residues or pollutants in the environment. The Acadian ${ }^{\circledR}$ (Acadian Seaplants liquid, Canada) stands out as one of the most used biostimulants in agriculture (Hurtado \& Critchley, 2018). Acadian is the trade name for the seaweed A. nudosum L. This is commonly used in agriculture as a growth stimulant, which contributes to the quality of different crops, in addition to increasing the photosynthetic rate. This is rich in many growth regulators such as auxins, gibberellins, cytokinins, macro and micronutrients such as $\mathrm{Ca}, \mathrm{K}$ and Mo. This substances are beneficial to the plant metabolism, which gives it the biostimulating effect (Acadian Agritech, 2009).

Several studies have already proven the beneficial effects of biostimulants applications (Oliveira et al., 2015, 2017). However, in most of these researches the biostimulant used was the Stimulate ${ }^{\circledR}$ (plant growth regulator of the chemical group composed of the hormones cytokinin, gibberellin and indolalkanoic acid). There is little information in the literature about the biostimulant Acadian ${ }^{\circledR}$ being used in cowpea, especially under salinity stress conditions.

Due to the above mentioned considerations, the hypothesis was raised that the biostimulant application can reduce the effects of salinity stress on cowpea. The objective of this work was to evaluate the effects of biostimulant application on the physiological responses of cowpea cultivars (Vigna unguiculata (L.) Walp.) irrigated with saline water.

\section{Material and Methods}

The study was carried out from April to June 2016 in a greenhouse in the Didactic Vegetable Garden of the Agrarian Sciences Center of the Department of Agronomic and Forest Sciences of the Federal Rural University of the Semi-Arid (UFERSA), in Mossoró, RN, Brazil (5 $5^{\circ} 11^{\prime} 31^{\prime \prime}$ S; 37²0'40" W; altitude $18 \mathrm{~m}$ ).

A mixture of soil and commercial substrate $\left(\right.$ Plantmax $\left.^{\circledR}\right)$ in a 3:6 ratio, was the material used as substrate. The soil used is classified as Eutrophic Haplic Planosol (EMBRAPA, 2013), collected in the 0-20 cm depth, and its physico-chemical characteristics are presented in Table 1.

Table 1. Physical and chemical characteristics of the substrate used in the study

\begin{tabular}{|c|c|c|c|c|c|c|c|c|c|}
\hline \multicolumn{10}{|c|}{ Chemical characteristics } \\
\hline $\mathrm{pH}$ & $\mathrm{OM}$ & $\mathrm{P}$ & $\mathrm{K}^{+}$ & $\mathrm{Na}^{+}$ & $\mathrm{Ca}^{2+}$ & $\mathrm{Mg}^{2+}$ & $\mathrm{Al}^{3+}$ & $\mathrm{H}^{+}$ & CEC \\
\hline$\left(\mathrm{H}_{2} \mathrm{O}\right)$ & ---- \% ---- & \multicolumn{3}{|c|}{ 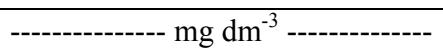 } & \multicolumn{5}{|c|}{ - } \\
\hline 6.5 & 1.0 & 64.4 & 7.2 & 3.2 & 2.5 & 1.8 & 0.0 & 0.0 & 4.5 \\
\hline \multicolumn{10}{|c|}{ Physical characteristics } \\
\hline \multicolumn{6}{|c|}{ Granulometric fraction $\left(\mathrm{g} \mathrm{kg}^{-1}\right)$} & \multirow{2}{*}{\multicolumn{2}{|c|}{ Textural class }} & & \\
\hline Sand & & Silt & & Clay & & & & & \\
\hline 820.2 & & 120.4 & & 59.4 & & Sandy & & & \\
\hline
\end{tabular}

Note: $\mathrm{OM}=$ Organic matter; $\mathrm{CEC}=$ Cation exchange capacity.

The experimental design was completely randomized, with the treatments arranged in a $5 \times 2 \times 2$ factorial scheme. The first factor was two electrical conductivities of the irrigation water $(\mathrm{ECW})\left(0.5\right.$ and $\left.5.0 \mathrm{dS} \mathrm{m}^{-1}\right)$; the second two cowpea cultivars (IPA-206 and BRS Guariba); and the third five biostimulant doses applied via leaves $\left(0,15,30,45,60 \mathrm{~mL}\right.$ of Acadian ${ }^{\circledR}$ per liter of water) with four replicates. Each experimental unit was represented by a $1.6 \mathrm{dm}^{-3}$ volumetric capacity plastic bag containing one plant. Five cowpea seeds were sown in each plastic bag, at a depth of two centimeters. Seven days after sowing, the thinning was performed, leaving in each bag the most vigorous plant. After that, the treatments with saline water irrigation started. 
For the lowest ECW $\left(0.5 \mathrm{dS} \mathrm{m}^{-1}\right)$, water from a deep well located at the UFERSA Central Campus was used. To prepare the water with the highest $\mathrm{ECW}\left(5.0 \mathrm{dS} \mathrm{m}{ }^{-1}\right)$, a mixture of the following salts: $\mathrm{NaCl}, \mathrm{CaCl}_{2} \cdot 2 \mathrm{H}_{2} \mathrm{O}$ and $\mathrm{MgCl}_{2} \cdot 6 \mathrm{H}_{2} \mathrm{O}$ was added to the $0.5 \mathrm{dS} \mathrm{m}^{-1}$ water, in a 7:2:1 ratio (Rhoades et al., 2000). The biostimulant used was the seaweed extract of the species Ascophyllum nodosum $\left(\right.$ Acadian $\left.^{\circledR}\right)$, composed of: $\mathrm{N}-8.12 ; \mathrm{P}-6.82$; $\mathrm{K}-12.00 ; \mathrm{Ca}-1.60 ; \mathrm{Mg}-2.03 ; \mathrm{S}-8.16 \mathrm{~g} \mathrm{~kg}^{-1} ; \mathrm{B}-5.74 ; \mathrm{Cu}-13.60 ; \mathrm{Fe}-11.5 ; \mathrm{Mn}-0.04 ; \mathrm{Zn}-24.40$ and $\mathrm{Na}-20000 \mathrm{mg} \mathrm{kg}^{-1}$; potassium hydroxide, with $61.48 \mathrm{~g} \mathrm{~L}^{-1}$ of water-soluble $\mathrm{K}_{2} \mathrm{O} ; 69.60 \mathrm{~g} \mathrm{~L}^{-1}$ of total organic carbon; and a density of $1.16 \mathrm{~g} \mathrm{dm}^{-3}$ (Silva et al., 2016). Two applications of biostimulant were carried out at 7 and 25 days after sowing. The applications were performed in the morning, starting at 8:00 am. The whole aerial part of the plant was sprayed until runoff, using a $5 \mathrm{~L}$ capacity hand sprayer, applying a water volume equivalent to $300 \mathrm{~L} \mathrm{ha}^{-1}$ (Abrantes et al., 2011). For the treatments that did not receive the biostimulant dose $(0 \mathrm{~mL}$ of Acadian $\left.^{B}\right)$, the plants were sprayed only with water, applying the same volume of the other treatments.

The following variables were evaluated at 40 days after sowing: chlorophyll content index (CCI), stomatal conductance $\left(g s ;\right.$ mol $\left.\mathrm{H}_{2} \mathrm{O} \mathrm{m}^{-2} \mathrm{~s}^{-1}\right)$, net photosynthesis $\left(A ; \mu \mathrm{mol} \mathrm{CO}_{2} \mathrm{~m}^{-2} \mathrm{~s}^{-1}\right)$, internal $\mathrm{CO}_{2}$ concentration $(C i$; $\left.\mu \mathrm{mol} \mathrm{CO}_{2} \mathrm{~m}^{-2} \mathrm{~s}^{-1}\right)$ and transpiration rate $\left(E ; \mathrm{mmol} \mathrm{H}_{2} \mathrm{O} \mathrm{m}^{-2} \mathrm{~s}^{-1}\right)$. The $g s, A, C i$ and $E$ measurements were performed using an infrared gas analyzer (IRGA, portable model LI-6400, li-color, Lincoln, Nebraska, USA), and the readings were performed between 08:00 and 10:00 am. The $\mathrm{CO}_{2}$ contents were set at $400 \mu \mathrm{mol} \mathrm{m} \mathrm{m}^{-2} \mathrm{~s}^{-1}$ and the luminous intensity at $1500 \mu \mathrm{mol}$ photons $\mathrm{m}^{-2} \mathrm{~s}^{-1}$. Young newly expanded, undamaged and well lit leaves (when the light intensity was greater than $1000 \mu \mathrm{mol}$ of photons $\mathrm{m}^{-2} \mathrm{~s}^{-1}$ ) were evaluated. The CCI was determined using a portable chlorophyll-meter (model CCM-200, Opti-Science), and two readings were performed per plant, always in the third and fourth leaf of each plant, counting from the apex.

At 45 days after sowing, the plants were harvested. The following variables were evaluated: shoot height (SH), measured with a ruler graduated in $\mathrm{cm}$; stem diameter (SD), determined at $3 \mathrm{~cm}$ from the ground, using a digital caliper; and shoot dry mass (SDM), where the aerial plant part (leaves + stem) was packed in paper bags and placed in a forced air oven at a temperature of $65 \pm 1{ }^{\circ} \mathrm{C}$ until reaching a constant mass. After that, the dried shoot was weighed in analytical balance to obtain its dry mass.

The data obtained were submitted to analysis of variance by the $F$ test $(p \leq 0.05)$, and the results were analyzed using the SISVAR software (Ferreira, 2011). The effect of the salinity and cultivars factors were analyzed using the Tukey's test $(\mathrm{p} \leq 0.05)$, while the biostimulant effect was evaluated by regression analysis.

\section{Results and Discussions}

There were triple interactions (cultivar $\times$ salinity $\times$ biostimulant) for the internal $\mathrm{CO}_{2}$ concentration, stomatal conductance, net photosynthesis, chlorophyll content index and shoot dry mass. For the shoot height, there was a double interaction between cultivar and biostimulant and between salinity and biostimulant. For the transpiration rate, there was an isolated effect of the cultivar and interaction between salinity and biostimulant. For the stem diameter, there was an isolated effect of the factors (Table 2).

Table 2. Analysis of variance summary for internal $\mathrm{CO}_{2}$ concentration $(\mathrm{Ci})$, stomatal conductance (gs), net photosynthesis (A), chlorophyll content index (CCI), shoot dry mass (SDM), shoot height (SH), transpiration rate (E), and stem diameter (SD) in cowpea (Vigna unguiculata (L.) Walp.) cultivars as a function of biostimulant doses and salinity of the irrigation water

\begin{tabular}{|c|c|c|c|c|c|c|c|c|c|}
\hline \multirow{2}{*}{ SV } & \multirow{2}{*}{$\mathrm{DF}$} & \multicolumn{8}{|c|}{ Mean Squares } \\
\hline & & $\mathrm{Ci}$ & Gs & $A$ & CCI & SDM & $\mathrm{SH}$ & $E$ & SD \\
\hline Blocks & 3 & $0.84^{\mathrm{ns}}$ & $1.31^{\mathrm{ns}}$ & $0.63^{\mathrm{ns}}$ & $0.68^{\mathrm{ns}}$ & $3.22^{\mathrm{ns}}$ & $3.29^{\text {ns }}$ & $1.80^{\mathrm{ns}}$ & $1.33^{\mathrm{ns}}$ \\
\hline Cultivar (C) & 1 & $0.00^{\mathrm{ns}}$ & $0.11^{\mathrm{ns}}$ & $19.04^{* *}$ & $88.79^{* *}$ & $8.34^{* *}$ & $0.00^{\mathrm{ns}}$ & $103.64^{* *}$ & $4.56^{* *}$ \\
\hline Salinity (S) & 1 & $127.17^{* *}$ & $1407.88^{* *}$ & $1628.79^{* *}$ & $164.38^{* *}$ & $629.18^{* *}$ & $140.71^{* *}$ & $1393.46^{* *}$ & $139.53^{\mathrm{ns}}$ \\
\hline Biostimulant (B) & 4 & $22.18^{* *}$ & $27.90^{* *}$ & $127.90^{* *}$ & $16.68^{* *}$ & $16.85^{* *}$ & $12.21^{* *}$ & $48.10^{* *}$ & $12.51^{* *}$ \\
\hline Interaction $\mathrm{C} \times \mathrm{S}$ & 1 & $0.001^{\mathrm{ns}}$ & $13.11^{* *}$ & $36.11^{* *}$ & $431.42^{* *}$ & $0.03^{\mathrm{ns}}$ & $0.09^{\mathrm{ns}}$ & $1.79^{\mathrm{ns}}$ & $0.32^{\mathrm{ns}}$ \\
\hline Interaction $\mathrm{C} \times \mathrm{B}$ & 4 & $5.43^{* *}$ & $18.32^{* *}$ & $9.49^{* *}$ & $31.49^{* *}$ & $0.58^{\mathrm{ns}}$ & $4.77^{* *}$ & $0.59^{\mathrm{ns}}$ & $0.99^{\mathrm{ns}}$ \\
\hline Interaction $\mathrm{S} \times \mathrm{B}$ & 4 & $9.98^{* *}$ & $40.40^{* *}$ & $36.42^{* *}$ & $83.93^{* *}$ & $0.98^{\mathrm{ns}}$ & $13.96^{* *}$ & $6.42^{* *}$ & $1.19^{\mathrm{ns}}$ \\
\hline Interaction $\mathrm{C} \times \mathrm{S} \times \mathrm{B}$ & 4 & $13.30^{* *}$ & $32.51^{* *}$ & $10.18^{* *}$ & $10.86^{* *}$ & $5.74^{* *}$ & $1.28^{\mathrm{ns}}$ & $1.57^{\mathrm{ns}}$ & $1.16^{\mathrm{ns}}$ \\
\hline $\mathrm{CV}(\%)$ & & 9.22 & 14.67 & 8.03 & 13.41 & 9.05 & 6.23 & 12.89 & 7.62 \\
\hline
\end{tabular}

Note. $\mathrm{SV}=$ Source of variation; $\mathrm{DF}=$ Degree of freedom; $\mathrm{CV}=$ Coefficient of variation; $(* *)$ Significant at $1 \%$ probability by F-test; $\left({ }^{\mathrm{ns}}\right)$ not significant. 
In general, cowpea cultivars irrigated with the highest $\mathrm{ECw}$ level $\left(5.0 \mathrm{dS} \mathrm{m}^{-1}\right)$ presented lower values of internal $\mathrm{CO}_{2}$ concentration $(\mathrm{Ci})$, stomatal conductance $(\mathrm{gs})$ and net photosynthesis $(\mathrm{A})$, in relation to those that were irrigated with water of lower $\mathrm{ECw}\left(0.5 \mathrm{dS} \mathrm{m}^{-1}\right)$. The reduction of these variables is possibly a reflection of the ionic and osmotic effects caused under salinity stress conditions. This first effect (ionic) results from reduced soil water potential, while the second one (osmotic) is caused by the ions accumulation in plant tissues (Munns \& Tester, 2008). Salinity stress can lead to stomatal closure and, as a result, reduce stomatal conductance. This results in lower intercellular $\mathrm{CO}_{2}$ availability in the leaves and carbon fixation inhibition, while reducing transpirational water loss, resulting in lower photosynthetic rates (Praxedes et al., 2010; Huang et al., 2015). In the literature, several researchers have already reported the negative effects of salinity on cowpea gas exchanges (Neves et al., 2009; Souza et al., 2011; Silva et al., 2013; Prazeres et al., 2015).

In relation to $C i$, in the plants of cultivar IPA-206 (Figure 1A) submitted to ECW of $0.5 \mathrm{dS} \mathrm{m}^{-1}$, there was a positive linear effect as the biostimulant concentrations increased and, according to the regression equation, plants treated with $60 \mathrm{~mL} \mathrm{~L}^{-1}$ of Acadian ${ }^{\circledR}$ provided the highest values, with $263.17 \mu \mathrm{mol} \mathrm{CO}_{2} \mathrm{~m}^{-2} \mathrm{~s}^{-1}$, representing a $15.9 \%$ increase compared to plants that did not receive biostimulant doses. In the ECw of $5.0 \mathrm{dS}$ $\mathrm{m}^{-1}$, increased biostimulant concentrations provided a quadratic effect, with a lower value $\left(142.74 \mu \mathrm{mol} \mathrm{CO} \mathrm{CO}^{-2}\right.$ $\left.\mathrm{s}^{-1}\right)$ recorded in the absence of the biostimulant, and a higher $\left(236.55 \mu \mathrm{mol} \mathrm{CO}_{2} \mathrm{~m}^{-2} \mathrm{~s}^{-1}\right)$ at the concentration of $33.4 \mathrm{~mL} \mathrm{~L}^{-1}$.

The increase of the biostimulant doses at the two levels of salinity promoted a quadratic effect on the $\mathrm{Ci}$ values in the cultivar BRS Guariba (Figure 1B) and, according to regression equations, the lowest values were verified in the absence of biostimulant $\left(0 \mathrm{~mL}\right.$ of Acadian $\left.{ }^{\circledR}\right)$. At the ECw of $0.5 \mathrm{dS} \mathrm{m}^{-1}$, the highest value was $251.67 \mu \mathrm{mol}$ $\mathrm{CO}_{2} \mathrm{~m}^{-2} \mathrm{~s}^{-1}$, obtained in the biostimulant dose of $33.7 \mathrm{~mL} \mathrm{~L}^{-1}$, whereas, at the ECW of $5.0 \mathrm{dS} \mathrm{m}^{-1}$, the highest value was $271.59 \mu \mathrm{mol} \mathrm{CO} \mathrm{m}^{-2} \mathrm{~s}^{-1}$, recorded at the dose of $51.22 \mathrm{~mL} \mathrm{~L}^{-1}$.

For the cultivar IPA-206 (Figure 1C), at the $\mathrm{ECw}$ of $0.5 \mathrm{dS} \mathrm{m}^{-1}$, there was a quadratic response in relation to the biostimulant concentrations to variable $g s$, with maximum value $\left(0.3586 \mathrm{~mol} \mathrm{H}_{2} \mathrm{O} \mathrm{m}^{-2} \mathrm{~s}^{-1}\right)$ in the treatment with $8.9 \mathrm{~mL} \mathrm{~L}^{-1}$, decreasing $\left(0.1144 \mathrm{~mol} \mathrm{H}_{2} \mathrm{O} \mathrm{m}^{-2} \mathrm{~s}^{-1}\right)$ in concentration with lower value in $60 \mathrm{~mL} \mathrm{~L}^{-1}$. On the other hand, at the ECw of $5.0 \mathrm{dS} \mathrm{m}^{-1}$, a higher value $\left(0.0699 \mathrm{~mol} \mathrm{H}_{2} \mathrm{O} \mathrm{m}^{-2} \mathrm{~s}^{-1}\right)$ was observed when $45.7 \mathrm{~mL} \mathrm{~L}^{-1}$ was applied, and the lowest value $\left(0.0276 \mathrm{~mol} \mathrm{H}_{2} \mathrm{O} \mathrm{m}^{-2} \mathrm{~s}^{-1}\right)$ was obtained in the absence of the biostimulant. The obtained results differ from those found by Anjos et al. (2015), who assessed different doses of Stimulate ${ }^{\circledR}$, Booster $^{\circledR}$ and Biozyme $\mathrm{TF}^{\circledR}$ on common bean (Phaseolus vulgaris L.) plants and did not observe any significant results for $g s$.

Regarding the cultivar BRS Guariba (Figure 1D), there was small oscillations in the gs values at the two ECw levels with the increase of biostimulant concentrations. The highest $g s$ values were obtained in the biostimulant concentrations of 34.3 and $22.3 \mathrm{~mL} \mathrm{~L}^{-1}$, at both ECw levels, whereas the lowest $g s$ values were obtained in the concentrations of 60 and $0.2 \mathrm{~mL} \mathrm{~L}^{-1}$, at the salinity levels of 0.5 and $5.0 \mathrm{dS} \mathrm{m}^{-1}$, respectively. This may have happened due to the fact that in high concentrations of salts (which hinders or reduces the absorption of water) the plants tend to close their stomata and, consequently, reduce their stomatal opening. Similarly to $g s$, at the $\mathrm{ECW}$ of $0.5 \mathrm{dS} \mathrm{m}^{-1}, A$ in the cultivar IPA-206 had a quadratic response to the effect of the biostimulant concentrations, presenting the higher value $\left(22.48 \mu \mathrm{mol} \mathrm{CO}_{2} \mathrm{~m}^{-2} \mathrm{~s}^{-1}\right)$ at the dose of $9.4 \mathrm{~mL} \mathrm{~L}^{-1}$ (Figure 1E). From this concentration on, a reduction was observed, reaching the lowest value $\left(10.94 \mu \mathrm{mol} \mathrm{CO} \mathrm{Cm}^{-2} \mathrm{~s}^{-1}\right)$ in the dose of $60 \mathrm{~mL} \mathrm{~L}^{-1}$. At the $\mathrm{ECW}$ of $5.0 \mathrm{dS} \mathrm{m}^{-1}$, increasing biostimulant concentrations resulted in a linear decrease response in $A$, and according to the regression equation, the lowest $A$ value $\left(4.69 \mu \mathrm{mol} \mathrm{CO} \mathrm{Cm}^{-2} \mathrm{~s}^{-1}\right)$ was found in the highest biostimulant concentration $\left(60 \mathrm{~mL} \mathrm{~L}^{-1}\right)$.

Regarding the $A$ in BRS Guariba cultivar (Figure 1F), there was a linear decreasing response to the biostimulant concentrations at the two ECw levels. The highest $A$ values were found in the absence of biostimulant and the lowest values in the dose of $60 \mathrm{~mL} \mathrm{~L}^{-1}$. The results found in the present study are similar to those of Prazeres et al. (2015), who verified a linear reduction in the cowpea net photosynthesis as the salinity of the irrigation water increased. 

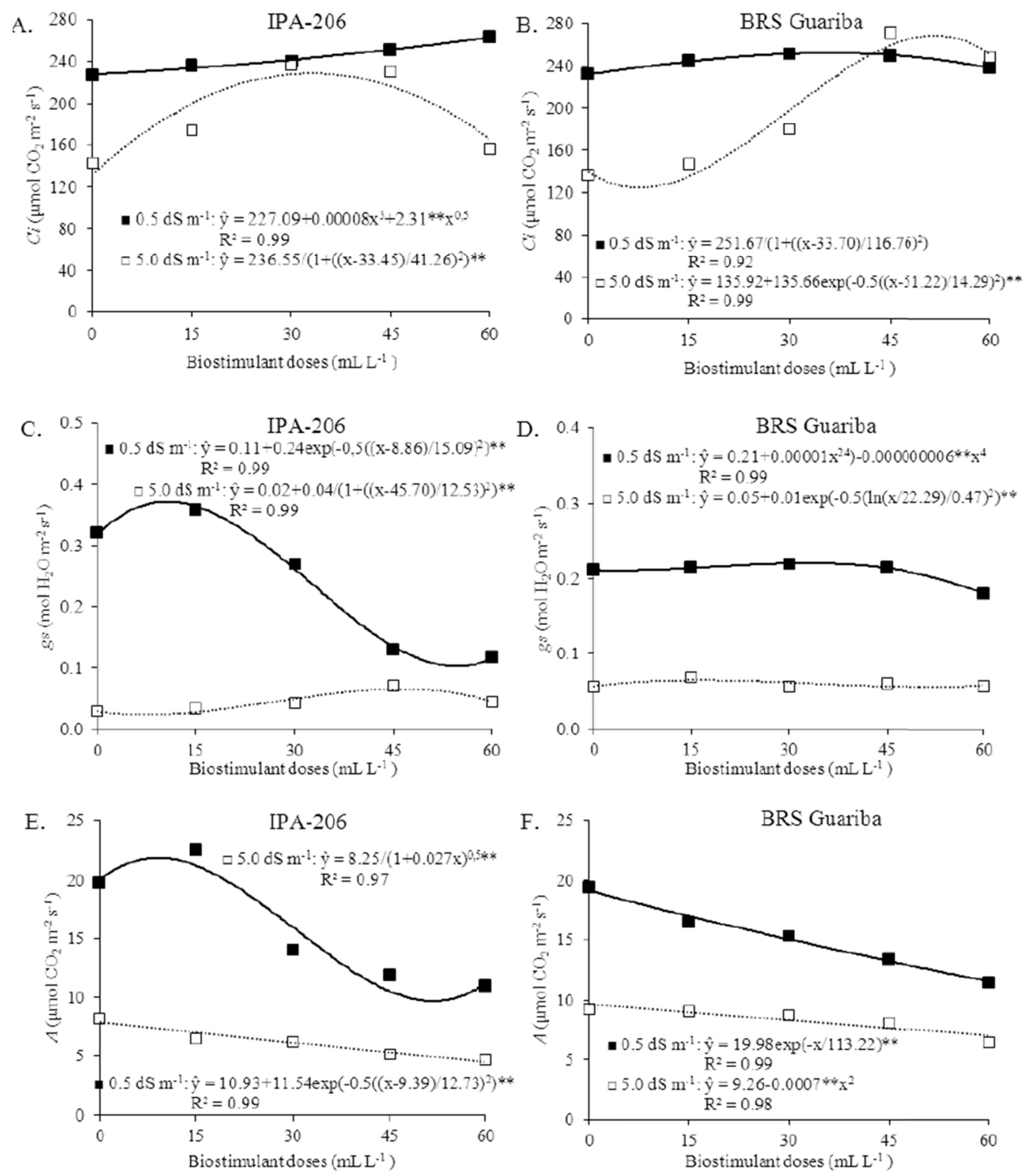

Figure 1. Internal $\mathrm{CO}_{2}$ concentration $(\mathrm{C} i)$, stomatal conductance $(g s)$ and net photosynthesis $(A)$ in the cowpea (Vigna unguiculata (L.) Walp.) cultivars IPA-206 (A, C and E) and BRS Guariba (B, D and F) as a function of biostimulant doses and salinity of the irrigation water

For the chlorophyll content index (CCI), at the ECw of $0.5 \mathrm{dS} \mathrm{m}^{-1}$, there were increasing linear responses as the biostimulant concentrations increased, in both cultivars (IPA-206 and BRS Guariba) (Figures 2A and 2B). It presented the highest values (41.61 and 18.71) in the biostimulant concentration of $60 \mathrm{~mL} \mathrm{~L}^{-1}$, which represents an increase of 102.68 and $78.02 \%$ for cultivars IPA-206 and BRS Guariba respectively, compared to plants that did not receive the biostimulant.

At the ECW of $5.0 \mathrm{dS} \mathrm{m}^{-1}$, the biostimulant application provided different responses in the CCI (Figures $2 \mathrm{~A}$ and 2B). For the two assessed cultivars there were quadratic responses with increasing biostimulant concentrations. The highest values were found in the concentrations of 9.41 and $25.19 \mathrm{~mL} \mathrm{~L}^{-1}$ for the cultivars IPA-206 and BRS Guariba, respectively. In the presence of high salinity $\left(5 \mathrm{dS} \mathrm{m}^{-1}\right)$, high doses of biofertilizer had a negative effect above $30 \mathrm{~mL} \mathrm{~L}^{-1}$. This may be linked to the fact that in high concentrations, hormones can cause harmful effects rather than increase the activity of the photosynthetic apparatus. 
The reduced CCI at the highest salinity level may be a result of salinity stress, which causes the destruction of the chlorophyll molecule and promotes instability of the pigment-protein complex (Jaleel et al., 2008). Another possible explanation for the reduction of CCI is the interference of saline ions in the de novo synthesis of new proteins, structural components of chlorophyll, rather than the degradation of chlorophyll (Jaleel et al., 2007). The salinity stress can also reduce the number of chloroplasts and lead to the decomposition of thylakoid membranes, resulting in increased chlorophyllase enzyme activity and, consequently, decreased chlorophyll content (Santos, 2004).

Plants cultivated under the ECw of $5.0 \mathrm{dS} \mathrm{m}^{-1}$ presented lower SDM compared to those submitted to the ECw of $0.5 \mathrm{dS} \mathrm{m}^{-1}$. For the cultivar IPA-206 (Figure 2C), at the ECw of $0.5 \mathrm{dS} \mathrm{m}^{-1}$, a linear and positive response was observed in the SDM with the increase of the biostimulant concentration and, according to the regression equation, plants treated with $60 \mathrm{~mL} \mathrm{~L}^{-1}$ provided the highest values $\left(2.74 \mathrm{~g} \mathrm{plant}^{-1}\right)$. At the salinity level of $5.0 \mathrm{dS}$ $\mathrm{m}^{-1}$, there was a quadratic response with maximum $\left(1.74 \mathrm{~g} \mathrm{plant}^{-1}\right)$ and minimum $\left(1.24 \mathrm{~g} \mathrm{plant}^{-1}\right) \mathrm{SDM}$ value obtained in the biostimulant concentration of $39.8 \mathrm{~mL} \mathrm{~L}^{-1}$ and $60 \mathrm{~mL} \mathrm{~L}^{-1}$, respectively. For the cultivar BRS Guariba (Figure 2D), at both ECw levels, quadratic responses to biostimulant concentrations were found, and, according to the regression equations, the biostimulant doses of 43.7 and $47.6 \mathrm{~mL} \mathrm{~L}^{-1}$ resulted in higher SDM values, obtained in the salinity levels of 0.5 and $5.0 \mathrm{dS} \mathrm{m}^{-1}$, respectively. The negative effect of saline irrigation water on cowpea dry biomass was also observed by other researchers (Prazeres et al., 2015; Aquino et al., 2017).
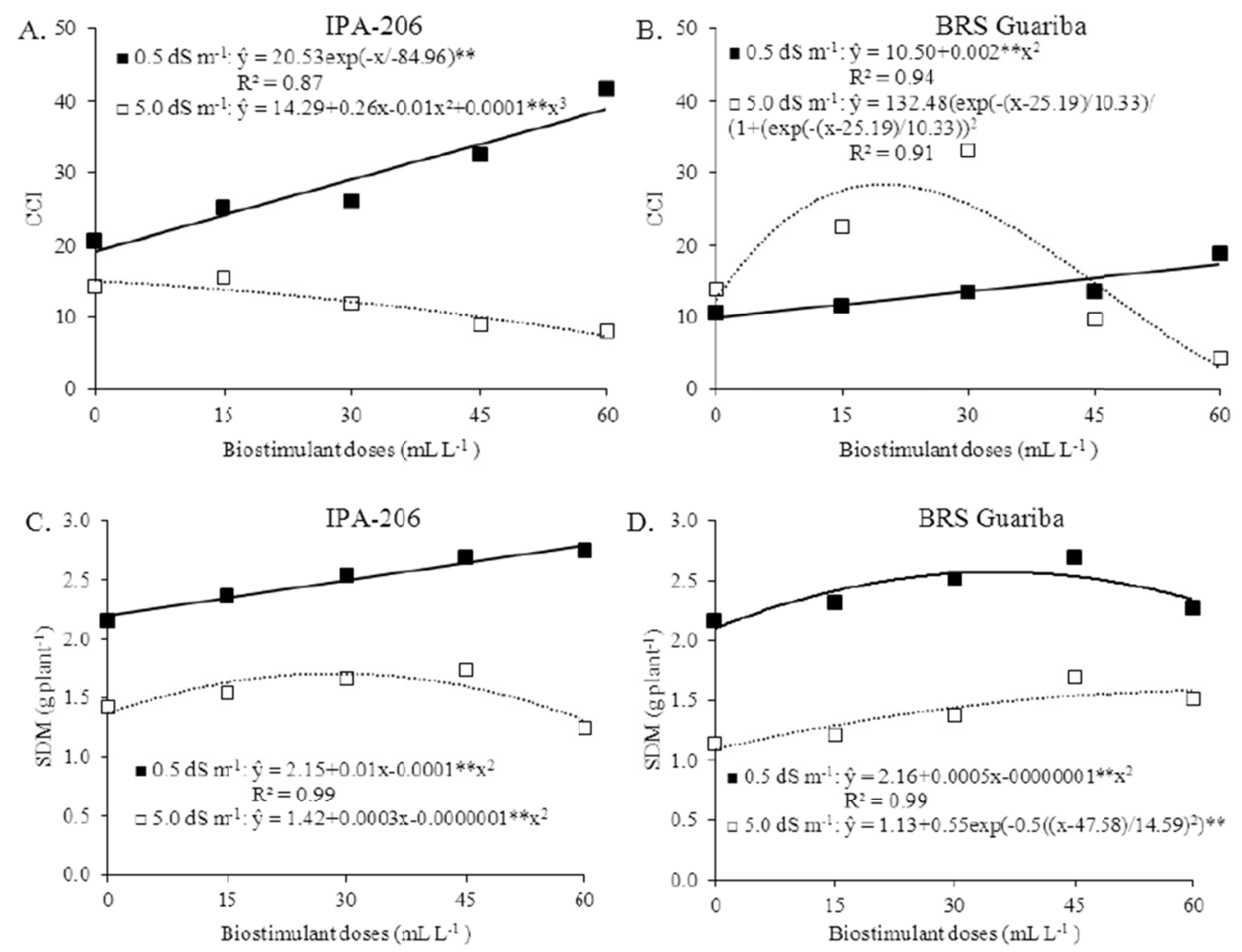

Figure 2. Chlorophyll content index (CCI) and shoot dry mass (SDM) in the cowpea (Vigna unguiculata (L.) Walp.) cultivars IPA-206 (A and C) and BRS Guariba (B and D) as a function of biostimulant doses and salinity of the irrigation water

The shoot height $(\mathrm{SH})$ was positively affected by the interaction between cultivars and biostimulant doses. Quadratic responses were observed with increasing biostimulant concentrations. The highest values were 24.51 and $23.71 \mathrm{~cm}$ for the cultivars IPA-206 and BRS Guariba, respectively (Figure 3A). These results are different from those found by Abrantes et al. (2011), who studied the effect of the biostimulant Stimulate ${ }^{\circledR}$ in common bean (Phaseolus vulgaris L.) and did not verify influence on the plants shoot height. 
The interaction between biostimulant doses and salinity also influenced the SH (Figure 3B). At the ECw of 0.5 $\mathrm{dS} \mathrm{m}{ }^{-1}, \mathrm{SH}$ increased as the biostimulant doses increased up to the concentration of $42.4 \mathrm{~mL} \mathrm{~L}^{-1}$, and the highest value $(25.82 \mathrm{~cm})$ represents a $17.5 \%$ raise in relation to the treatment without biostimulant. At the ECw of $5.0 \mathrm{dS}$ $\mathrm{m}^{-1}$, from the biostimulant concentration of $19.7 \mathrm{~mL} \mathrm{~L}^{-1}$ on, the plants presented a reduction in the $\mathrm{SH}$, when it was obtained the highest value, with $22.87 \mathrm{~cm}$. When evaluating the same salinity levels and the application of the biostimulant Stimulate ${ }^{\circledR}$ on cowpea, Oliveira et al. (2013) did not verify any effect on the plants shoot height.

In a study by Aquino et al. (2017), plants shoot height was severely affected with increasing salinity levels. The effect of salinity on plant growth can be explained by the impairment of biochemical and physiological functionalities, which are linked to toxic, osmotic and nutritional effects of the salts accumulation in the plants root zone (Taiz et al., 2017).
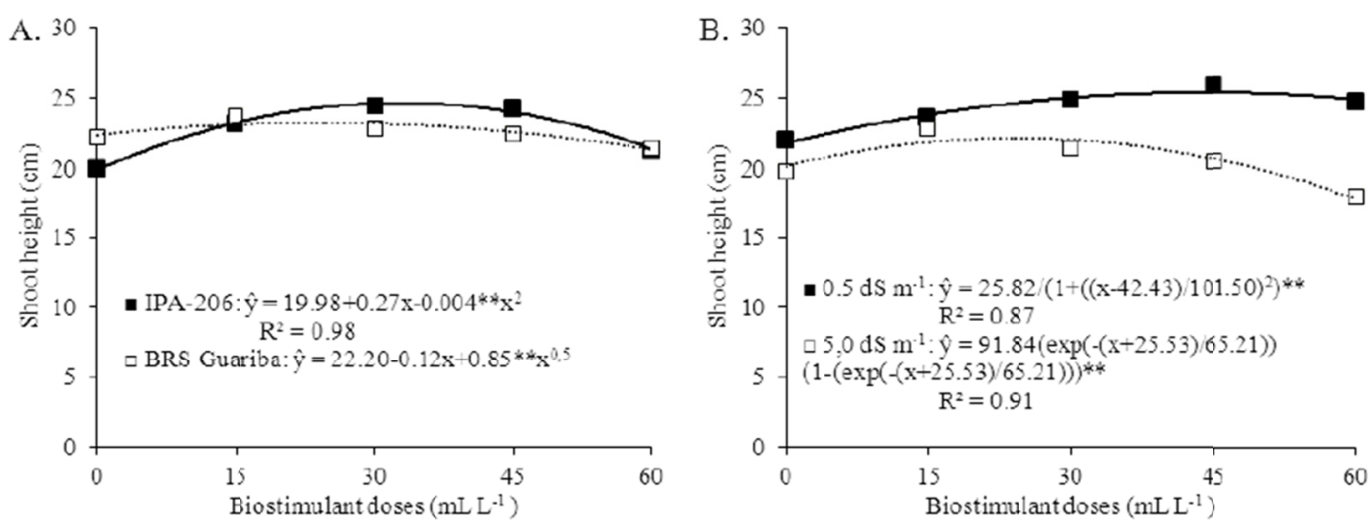

Figure 3. Shoot height on the cowpea (Vigna unguiculata (L.) Walp.) cultivars IPA-206 and BRS Guariba (A) and salinities of the irrigation water (B), as a function of biostimulant doses

The transpiration rate $(E)$ was linearly and negatively influenced as the biostimulant concentration increased and, according to the regression equation, the concentration of $60 \mathrm{~mL} \mathrm{~L}^{-1}$ resulted in lower values, with decreases of approximately 54 and $121 \%$ at the ECw of 0.5 and $5.0 \mathrm{dS} \mathrm{m}^{-1}$, respectively (Figure 4).

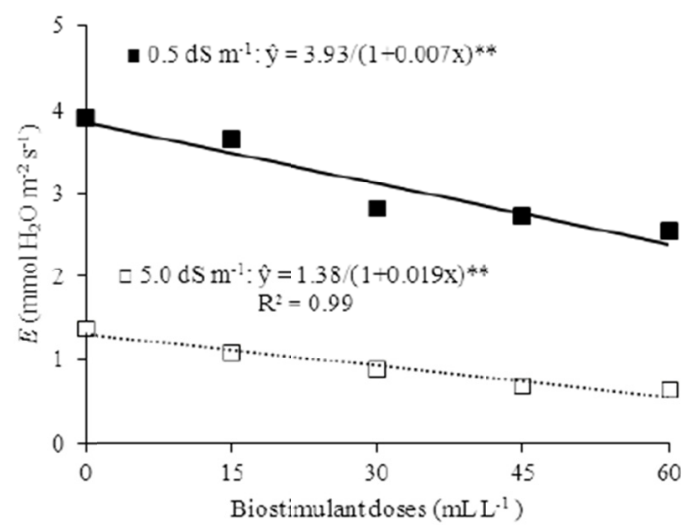

Figure 4. Transpiration rate (E) in cowpea (Vigna unguiculata (L.) Walp.) as a function of biostimulant doses and salinity of the irrigation water

For the stem diameter (Figure 5), increases in the biostimulant concentration had a linear and positive effect. The highest value was $4.53 \mathrm{~mm}$, recorded in the concentration of $60 \mathrm{~mL} \mathrm{~L}^{-1}$, which corresponds to a $18.27 \%$ increase in relation to the treatment with absence of biostimulant. These results are different from those found by Santos et al. (2013), who verified no effect of the biostimulants BU-RG ${ }^{\circledR}, B U-\mathrm{VG}^{\circledR}$ and BU-EC ${ }^{\circledR}$ on corn (Zea mays L.) stalk diameter. 


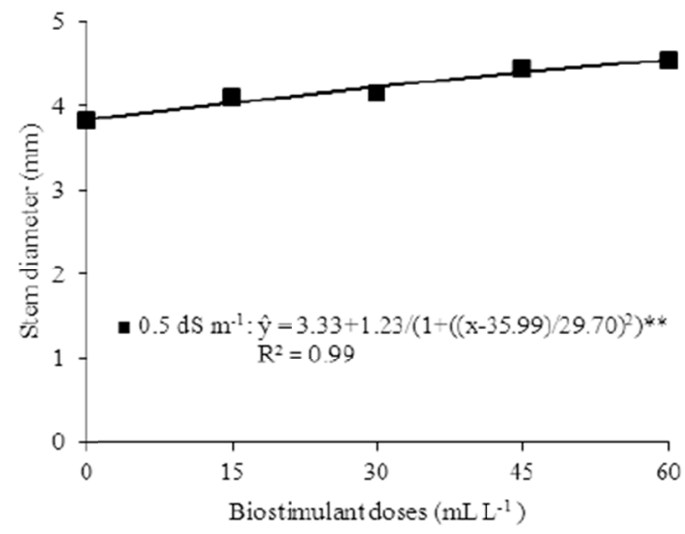

Figure 5. Stem diameter of cowpea (Vigna unguiculata (L.) Walp.) as a function of biostimulant doses

In general, it was verified that the highest biostimulant concentration $\left(60 \mathrm{~mL} \mathrm{~L}^{-1}\right)$, under high salinity conditions, intensified the saline stress effects on cowpea plants, by reducing its physiological and growth characteristics. These reductions probably occurred because the high biostimulant concentration enhanced the osmotic effects of salinity, hindering water absorption by the plants, as well as the ionic effects, that cause the increase of ions inside the cells, leaf injuries or reduced essential elements absorption (Munns, 2005). On the other hand, under favorable environmental conditions, such as low salinity levels, the biostimulant application can improve the crops growth characteristics. These results coincide with those found by Oliveira et al. (2017), who verified that the use of the biostimulant Stimulate ${ }^{\circledR}$ favors the cowpea growth and biomass production, but it is only effective in the absence of salinity stress.

\section{Conclusions}

The biostimulant application was not efficient in attenuating the salinity stress effect on the development of cowpea (Vigna unguiculata (L.) Walp.) cultivars. The higher biostimulant concentrations along with the use of saline water increased the negative effects of salinity on the chlorophyll content index, net photosynthesis and transpiration rate of cowpea cultivars. There was no difference between the cowpea cultivars regarding salinity stress tolerance and exogenous biostimulant application, since the studied variables were significantly affected and at similar intensities, except for the chlorophyll content index.

\section{References}

Abrantes, F. L., Sá, M. E., Souza, L. C. D., Silva, M. P., Simidu, H. M., Andreotti, M., Buzetti, S., Valério Filho, W. V., \& Arruda, N. (2011). Uso de regulador de crescimento em cultivares de feijão de inverno. Pesquisa Agropecuária Tropical, 41(2), 148-154. https://doi.org/10.5216/pat.v41i2.8287

Acadian Agritech. (2009). Ciência das Plantas (Site Institucional). Retrieved from http://www.acadianagritech.ca/ portuguese/PSansA.htm

Anjos, D. N., Vasconcelos, R. C., Mendes, H. T. A., Alcantara, A. S. A., \& Viana, A. E. S. (2015). Biostimulants, macro and micronutrient fertilizer influence on common bean crop in Vitória da Conquista-Ba, Brazil. African Journal of Agricultural Research, 10(16), 1891-1897. https://doi.org/10.5897/AJAR2014.9359

Aquino, J. P. A., Bezerra, A. A. C., Alcântara Neto, F., Lima, C. J. G. S., \& Sousa, R. R. (2017). Respostas morfofisiológicas de genótipos de feijão-caupi à salinidade da água de irrigação. Revista Caatinga, 30(4), 1001-1008. https://doi.org/10.1590/1983-21252017v30n421rc

Ayers, R. S., \& Westcot, D. W. (1999). A qualidade da água na agricultura (2nd ed., p. 153). Estudos FAO: Irrigação e Drenagem, 29.

CONAB (Companhia Nacional de Abastecimento). (2018). Acompanhamento da safra brasileira de grãos 2017/2018. Retrieved March 20, 2018, from http://www.conab.gov.br/OlalaCMS/uploads/arquivos/ 18_03_13_14_15_33_grao_marco_2018.pdf

EMBRAPA (Empresa Brasileira de Pesquisa Agropecuária). (2013). Sistema brasileiro de classificação de solos (3rd ed., p. 353). Brasília: EMBRAPA.

Ferreira, D. F. (2011). Sisvar: A computer statistical analysis system. Ciência e Agrotecnologia, 35(6), 1039-1042. https://doi.org/10.1590/S1413-70542011000600001 
Huang, C. J., Wei, G., Jie, Y. C., Xu, J. J., Zhao, S. Y., Wang, L. C., \& Anjum, S. S. (2015). Responses of gas exchange, chlorophyll synthesis and ROS-scavenging systems to salinity stress in two ramie (Boehmeria nivea L.) cultivars. Photosynthetica, 53(3), 455-463. https://doi.org/10.1007/s11099-015-0127-0

Hurtado, A. Q., \& Critchley, A. T. (2018). A review of multiple biostimulant and bioeffector benefits of AMPEP, an extract of the brown alga Ascophyllum nodosum, as applied to the enhanced cultivation and micropropagation of the commercially important red algal carrageenophyte Kappaphycus alvarezii and its selected cultivars. Journal of Applied Phycology, 1-15. https://doi.org/10.1007/s10811-018-1407-4

Jaleel, C. A., Manivannan, P., Lakshmanan, G. M. A., Sridharan, R., \& Panneerselvam, S. R. (2007). NaCl as a physiological modulator of proline metabolism and antioxidant potential in Phyllanthus amarus. Comptes Rendus Biologies, 330(11), 806-813. https://doi.org/10.1016/j.crvi.2007.08.009

Jaleel, C. A., Sankar, B., Sridharan, R., \& Panneerselvam, R. (2008). Soil salinity alters growth, chlorophyll content, and secondary metabolite accumulation in Catharanthus roseus. Turkish Journal of Biology, 32(2), 79-83.

Munns, R. (2005). Genes and salt tolerance: bringing them together. New Phytologist, 167, $645-663$. https://doi.org/10.1111/j.1469-8137.2005.01487.x

Munns, R., \& Tester, M. (2008). Mechanisms of salinity tolerance. Annual Review of Plant Biology, 59, 651-681. https://doi.org/10.1146/annurev.arplant.59.032607.092911

Neves, A. L. R., Lacerda, C. F., Guimarães, F. V., Gomes Filho, E., \& Feitosa, D. R. C. (2009). Trocas gasosas e teores de minerais no feijão-de-corda irrigado com água salina em diferentes estádios. Revista Brasileira de Engenharia Agrícola e Ambiental, 13, 873-881. https://doi.org/10.1590/S1415-43662009000700009

Oliveira, F. A., Medeiros, J. F., Alves, R. C., Lima, L. A., Santos, S. T., \& Régis, L. R. L. (2015). Produção de feijão caupi em função da salinidade e regulador de crescimento. Revista Brasileira de Engenharia Agrícola e Ambiental, 19(11), 1049-1056. https://doi.org/10.1590/1807-1929/agriambi.v19n11p1049-1056

Oliveira, F. A., Medeiros, J. F., Cunha, R. C., Souza, M. W. L., \& Lima, L. A. (2016). Uso de bioestimulante como agente amenizador do estresse salino na cultura do milho pipoca. Revista Ciência Agronômica, 47(2). https://doi.org/315.10.5935/1806-6690.20160036

Oliveira, F. A., Medeiros, J. F., Oliveira, M. K. T., Souza, A. A. T., Ferreira, J. A., \& Souza, M. S. (2013). Interação entre salinidade e bioestimulante na cultura do feijão caupi. Revista Brasileira de Engenharia Agrícola e Ambiental, 17(5), 465-471.

Oliveira, F. A., Oliveira, M. K. T., Lima, L. A., Alves, R. C., Régis, L. R. L., \& Santos, S. T. (2017). Estresse salino e biorregulador vegetal em feijão caupi. Irriga, 22(2), 314-329.

Praxedes, S. C., Lacerda, C. F., Damatta, F. M., Prisco, J. T., \& Gomes Filho, E. (2010). Salt tolerance is associated with differences in ion accumulation, biomass allocation and photosynthesis in cowpea cultivars. Journal of Agronomy and Crop Science, 196, 193-204. https://doi.org/10.1111/j.1439-037X.2009.00412.x

Prazeres, S. S., Lacerda, C. F., Barbosa, F. E. L., Amorim, A. V., Araujo, I. C. S., \& Cavalcante, L. F. (2015). Crescimento e trocas gasosas de plantas de feijão-caupi sob irrigação salina e doses de potássio. Revista Agro@mbiente On-line, 9(2), 111-118.https://doi.org/10.18227/1982-8470ragro.v9i2.2161

Rhoades, J. P., Kandiah, A., \& Mashali, A. M. (2000). The use saline waters for crop production (p. 117). Campina Grande: UFPB.

Santos, C. V. (2004). Regulation of chlorophyll biosynthesis and degradation by salt stress in sunflower leaves. Scientia Horticulturae, 103, 93-99. https://doi.org/10.1016/j.scienta.2004.04.009

Santos, J. A. S., Teodoro, P. E., Correa, A. M., Soares, C. M. G., Ribeiro, L. P., \& Abreu, H. K. A. (2014). Desempenho agronômico e divergência genética entre genótipos de feijão-caupi cultivados no ecótono Cerrado/Pantanal. Bragantia, 73(4), 377-382. https://doi.org/10.1590/1678-4499.0250

Santos, V. M., Melo, A. V., Cardoso, D. P., Gonçalves, A. H., Varanda, M. A. F., \& Taubinger, M. (2013). Uso de bioestimulantes no crescimento de plantas de Zea mays L. Revista Brasileira de Milho e Sorgo, 12(3), 307-318. https://doi.org/10.18512/1980-6477/rbms.v12n3p307-318

Silva, C. C., Arrais, Í. G., Almeida, J. P., Dantas, L. L., Silva, F. S., Silva, C. C. D., \& Mendonça, V. (2016). Extrato da alga Ascophyllum nodosum (L.): Le Jolis na produção de porta-enxertos de Anonna glabra L. Revista de Ciências Agrárias, 39(2), 234-247. 
Silva, F. L. B., Lacerda, C. F., Neves, A. L. R., Sousa, G. G., Sousa, C. H. C., \& Ferreira, F. J. (2013). Irrigação com águas salinas e uso de biofertilizante bovino nas trocas gasosas e produtividade de feijão-de-corda. Irriga, 18(2), 304-317. https://doi.org/10.15809/irriga.2013v18n2p304

Souza, R. P., Machado, E. D., Silveira, J. A. G., \& Ribeiro, R. V. (2011). Fotossíntese e acúmulo de solutos em feijoeiro caupi submetido à salinidade. Pesquisa Agropecuária Brasileira, 46(6), 586-592. https://doi.org/ 10.1590/S0100-204X2011000600003

Taiz, L., Zeiger, E., Moller, I. A., \& Murphy, A. (2017). Fisiologia e desenvolvimento vegetal (6th ed., p. 888). Porto Alegre: Artmed.

\section{Copyrights}

Copyright for this article is retained by the author(s), with first publication rights granted to the journal.

This is an open-access article distributed under the terms and conditions of the Creative Commons Attribution license (http://creativecommons.org/licenses/by/4.0/). 